\title{
Using Student Narratives to Understand the Perceived Impact of First-Year Seminar Participation
}

\author{
Stephanie M. Foote
}

The purpose of this multi-campus study was to determine how participating in a first-year seminar impacts students during the first semester of college. In the years since the first credit-bearing first-year seminar was offered at Reed College in 1911 (Gordon \& Grites, 1984), many campuses have created seminars that address a variety of subject matter and meet the needs of an institution and its students. The customized nature of contemporary seminars has caused much of the course assessment and research to focus on measuring the impact of these institution-specific courses on retention (Porter \& Swing, 2006). Qualitative methods were used in this study to identify additional ways first-year seminar participation influences the early college experience of students enrolled in the course. The study found that participating in a first-year seminar contributed to students' feelings of confidence in academic skills and abilities, as well as the connections they developed with their peers and seminar instructor. Several aspects of the first-year seminars in this study, including the content and ways in which the course was taught, were found to contribute to the perceptions of the participants.

Many orientation programs and first-year seminars share the common goal of helping students in the early college transition (Hunter, Skipper, \& Linder, 2005). Through these programs and classes, students often have an opportunity to learn about resources, get involved in campus traditions, and begin to understand academic requirements and expectations. Although the approach to sharing this type of information may vary from institution to institution, current literature illustrates that many orientation programs and first-year seminars have a similar focus and historical context. First-year seminars grew from early orientation and first-year advising programs; the first were at Harvard and Johns Hopkins in the late 1800s (Gordon, 1989). These programs became part of the "orientation movement" (Fitts \& Swift, 1928), as it was first known, which encompassed the efforts of many colleges and universities to help students adjust to the first year of college.

Orientation programs and first-year seminars have changed over time to meet the diverse needs of institutions and the unique early college experience of students. Almost 100 years after the initial credit-bearing first-year seminar was offered at Reed College (Gordon \& Grites, 1984), the first year of college continues

Stephanie M. Foote (stephanief@usca.edu) is the Director of Academic Success Center and First-Year Experience at the University of South Carolina Aiken. She was the 2009 recipient of the NODA Outstanding Research Award. 
to be a point of focus for many colleges and universities. What has changed over time is the philosophy and approach institutions take in their work with first-year students, thus impacting the look of first-year seminars (Hunter \& Linder, 2005). Gordon and Grites (1984) described the need for creating campus-specific versions of first-year seminars in saying that, "The primary purpose of a freshman seminar course must be defined by the needs of the students attending a specific campus" (p. 316). Although seminars are often created with the goal of first-year student adjustment (Hunter \& Linder, 2005), differences in the specific course content, who teaches the course, the methods used to teach the course, and the number of credit hours awarded have caused much of the first-year seminar evaluation to focus on measuring the outcomes related to these institution-specific courses (Porter \& Swing, 2006).

Existing research on first-year seminars has demonstrated that the course can positively affect student retention and academic success (Boudreau \& Kromrey, 1994; Davis, 1992; Fidler, 1991; Schnell \& Doetkott, 2002; Shanley \& Witten, 1990; Weissman \& Magill, 2008). Other studies have investigated the impact of the course on social integration or adjustment, and several have found that students who participated in a first-year seminar demonstrated greater levels of social adjustment than students who did not participate in the course (Maisto \& Tammi, 1991; Sanders \& Burton, 1996; Schwitzer, McGovern, \& Robbins, 1991; Starke, Harth, \& Sirianni, 2001).

The purpose of this study was to further extend the research on first-year seminars by determining how participating in the seminar impacts students during the first semester of college. The following research questions were used to guide the study: a) What are students' perceptions of the impact, if any, of first-year seminars on their ideas and actions concerning the college experience while they are taking the course? b) What aspects of the first-year seminar have most influenced student perceptions? c) To what extent do these perceptions of impact vary based on the type of first-year seminar section ${ }^{1}$ ? d) What do students enrolled in a first-year seminar perceive to be the purpose of the course?

\section{Methodology}

This study used qualitative methods to examine the early college experience and the perceived impact of first-year seminar participation on that experience. The methods used in this multi-site study extended the current research on first-year seminars by "capturing many of the subtle and fine-grained complexities of college impact than the more traditional quantitative approaches" (Pascarella, 1991, p. 463). These complexities are largely absent in the existing research. Further, these methods allowed the examination of the intertwined relationship between perceptions and personal meaning, which allow orientation/transition professionals to develop a deeper understanding of the early college experience and "the meaning they [students] make of that experience" (Seidman, 1998, p. 3).

\footnotetext{
${ }^{1}$ In this study, type of seminar section includes discipline or major-specific, which are sections for students in particular majors, and general sections, which have no disciplinary or major affiliation.
} 
The research took place at three institutions: the University of South Carolina Columbia (USC), Clemson University, and the University of South Carolina Aiken (USC Aiken). These sites were chosen because they offered the same type of first-year seminar: an extended orientation course ${ }^{2}$, and each institution offered sections of the seminar for specific majors, special groups, and several general sections. Finally, the three sites in this study offered a unique range of credit hours: one seminar was a one credit hour course, one was a two credit hour course, and one was a three credit hour course. The similarities in course content and section type, as well as differences in credit hours, allowed for analysis within the seminars and cross-site comparisons. Table 1 provides the course acronyms for the first-year seminars at the institutions in this study, number of credit hours awarded for the seminars, number of sections offered, and total enrollment in the courses at the time the study was conducted.

TABLE 1

\section{Characteristics of First-Year Seminars Selected for Study}

\begin{tabular}{llccc} 
Institution & Course & Credit Hours & Sections & Course Enrollment \\
\hline USC & U101 & 3 & 110 & 2,913 \\
Clemson & CU 101 & 2 & 43 & 817 \\
USC Aiken & AFYS 101 & 1 & 15 & 233
\end{tabular}

\section{Participants and Participant Selection}

Purposeful sampling (Patton, 1990) was used to choose participants who were enrolled in a first-year seminar at each one of the three study sites. Sections of the first-year seminar were chosen at the study sites to allow analysis across seminar type. Specifically, participants were selected using the following criteria: enrolled in a major-specific section (nursing, education, or business), enrolled in a section for a special population, or enrolled in a general section (no academic or major affiliation). Administrative offices responsible for each of the first-year seminars in the study were contacted to obtain the names of students enrolled in the selected sections. A total of 271 students enrolled in these sections of the seminars were contacted by e-mail, and 58 students agreed to participate in the study. In-depth interviews were conducted with 18 students ( 5 men and 13 women), traditional-aged (18-19), who were enrolled in 12 or more credit hours at the

\footnotetext{
${ }^{2}$ Extended orientation courses generally include information about the institution and resources to help develop or refine academic skills (Griffin, Romm, \& Tobolowsky, 2008).
} 
time the interviews were conducted. A total of five participants described themselves as "first generation," or the first in their immediate families to pursue higher education.

\section{Data Collection and Analysis}

Most of the data in this study were collected through semi-structured, one-on-one interviews conducted at each of the three study sites after the middle of the fall semester. It was assumed that because the interviews were conducted after the midpoint of the semester, participants would still be involved in the transition to college but beginning to make meaning of those experiences. The interview protocol was developed to elicit participant narratives, and drew from aspects of the College Experience Model (Reason, Terenzini, \& Domingo, 2006). In particular, variables in the "Student Precollege Characteristics \& Experiences" and "Individual Student Experiences" parts of the model were used in the development of the interview protocol because of their relationship to the research questions. Following the transcription of the interviews, a copy was e-mailed to the participants, asking them to review the transcript for accuracy.

The data collected in this study were first transcribed and then analyzed inductively. Following the initial analysis, a coding system was developed, and the constant comparative method (Bogdan \& Biklen, 1998) was used to identify recurring ideas, perceptions, and experiences that emerged. Themes were revised throughout the process of data collection and analysis to capture new themes that emerged or those that became subsumed within existing categories. Finally, data from the syllabi of the first-year seminar sections chosen for the study were also gathered and analyzed to compare the stated purposes of the courses with participant perceptions.

\section{Limitations}

There are several limitations in this study. First, students self-selected; thus the perceptions and experiences of these 18 participants cannot be generalized to all of the students in seminars in the study. With a limited number of participants, it was also not possible to account for all of the variables associated with each first-year seminar (e.g., instructor training and background, all types of sections, etc.). Finally, the study was limited by time restrictions on the period of data collection. Although students were interviewed in the first semester of their first year, it is possible that participation in the first-year seminar will continue to impact them throughout their remaining undergraduate experience.

\section{Findings}

The narratives of the participants demonstrate the nuanced experiences of students in their early college experience, but these stories also reveal similarities in student perceptions of the impact of first-year seminar participation on those 
experiences. The following section captures the student narratives and is organized using the following three themes that emerged from the data: a) increased feelings of academic confidence, b) feeling of support from faculty and staff, and c) a connection to peers.

\section{Increased Feelings of Academic Confidence}

This theme captured the participants' perceptions of the confidence they gained as a result of activities or assignments in the class. Ten of the 18 students perceived that the first-year seminar had provided them with some level of academic confidence. The perceptions within this theme included feeling confident because the class was easy and helped to become more prepared for larger assignments in academic classes. For example, Emma, a student in a major-specific section of the first-year seminar, said, "It was kind of the first essay I had done in college, so it ... got me at ease about writing essays and how they graded them. Now I'm not that scared."

Much like Emma, Libby mentioned how the detailed feedback she had received on writing assignments in her general section of U101 helped her better understand what professors expected:

We wrote a paper and she gave us feedback on it. It was helpful because I haven't written a paper in a while because I'm not in English this semester because I exempted out of that, and I haven't ever written a paper for a college professor. I was really able to use the feedback when I wrote a paper for my nursing class.

Similarly, Claire talked about how the writing in her major-specific class helped her learn how to express her thoughts more clearly: "I learned from this class that once I put my thoughts on paper, I could see how things could come together. It just made sense and helped me keep focused."

Others mentioned how they felt more confident in the first-year seminar class because they were interested in the material. For Jennifer, her major-specific section of the seminar provided skills to manage her time, as well examples of various strategies for studying:

We've gone over different ways to study and how to manage your time bettersome of it is stuff you've heard your whole life, but put together, that's been helpful. We also went over different ways to outline, and I've used that when I study for my science classes.

Much like Jennifer, Chantel found that strategies she learned in CU 101 helped her develop learning skills that she used in other classes:

To be honest, I really didn't know how to study. As long as I paid attention in class in high school, I could either not study at all and make an "A" or I could read the material the night before the test and make a 100. Now I have to study so much, and it's so much material. I have to start way ahead of time. In CU 101, I've definitely learned to review notes before my classes. Now I'm just kind of flipping through the stuff for my class each morning. 
Chantel later described how she learned to adapt her note taking and reading strategies to negotiate the amount of work she had for each of her classes. She said these strategies largely came from what she learned in her CU 101 class.

Some participants said they found the class to be "easy" when compared to the other classes they were taking. Several said that the class was easy because the content was common sense to them. Jake talked about how the information in his U101 class repeated much of what he learned in high school: "The stuff that we learned I already knew and have been using it. We've learned about study skills and how to make a planner for the week; I've been using that since high school." Emma also mentioned that much of the information about learning skills and strategies repeated what she had learned and had been using:

At the beginning it was just kind of things that people usually come out of high school knowing, like manage your time, go to class, that kind of stuff. They were just kind of reiterating a lot of orientation lectures that we had to sit through. I felt like that didn't really teach you anything new.

Anna and several other participants agreed that the class was easy, but for her, knowing she was doing well helped her feel more confident:

It's just an easy class; it's not something that you really have to study hours for because the concepts really aren't that difficult. So, I'm definitely doing really well in there, and I'm excited. My other classes are A's and high B's; they're not that far behind, but they're not almost 100\% like CU 101 is.

Anna further explained that the assignments, while almost as many as the other classes she was taking, were easier for her because they were opinion-based. Similar to Anna's experience in the seminar, Kate also indicated the class was easier than the others she was taking. After receiving her final grade in the class ${ }^{3}$, Kate said,

The class is something I can do that's easy. In my other classes I find myself always studying, always doing this, always going to the Math Lab or Writing Room. When I got that " $\mathrm{A}$ " I was like "Okay, I have at least one ' $\mathrm{A}$ ' on my transcript already." I was so happy.

Travis, a first-generation student, also mentioned that his first-year seminar grade was higher than his grades in the other classes he was taking "because it's not as intense as my other classes." Only one student, Marco, who was taking a major-specific section of the seminar, found the class to be more challenging than he expected: "It's not like a really easy class that you can just take for an 'A.' You actually have to do a lot of work; the most work out of all of my classes has been in U101."

\section{Feeling of Support from Faculty and Staff}

The instructors of the first-year seminar sections in this study-four faculty

\footnotetext{
${ }^{3}$ AFYS 101 is an 8-week course and had finished one week before the data were collected in this study.
} 
and nine staff members-all had participated in some type of instructor training but had varying amounts of experience teaching the course. At the time the data were collected, only a few participants had interacted with their instructors outside of class, and many of those interactions were limited to e-mail messages. Yet, when asked if they thought they could meet with their instructor outside of class, or if they thought they would stay in contact with their instructor even after the class ended, 15 participants indicated that they would.

A total of three participants talked specifically about how they had or would seek their instructor's guidance if they were faced with an academic issue or decision. Jessica, a student in a general section of the first-year seminar, had consulted with her seminar instructor on several occasions before making academic decisions, including a time when she was contemplating a change of major. Jessica said, "When I was making my decision about changing my major, she was one of the people I went to and talked to because I knew she could help me through this." Although Jackie, a student in a major-specific seminar, had not yet met with her first-year seminar instructor, she said, "I could see myself talking to him or asking questions about what I need to do for my major or if I'm having problems." Bradley, like Jackie, had not met with his seminar instructor outside of class, but he talked about why he would go to her if he needed help: "She knew my name before I knew hers, which is really kind of rare. I don't even think any of my other teachers know me at all, my name or nothing." He further explained, "I think she would definitely be able to help me out; if I had to drop a class, or if I maybe was in a spot academically, losing a scholarship, I would definitely go to her first."

Like Bradley, half of the participants in the study mentioned specific aspects of their instructors' behavior, characteristics, or teaching styles, and their perception of the impact of those aspects. Travis talked about how friendly his first-year seminar instructor was, and how she would always address the students in the class by name. Emma described similar characteristics in her seminar instructor, "He was very personable. He would tell us about his college experience, and he said if it wasn't time for you to go to college, that was fine." For Marco, his instructor was someone he described as approachable: "He's probably the one I talk to the most, actually. I like him a lot; he's a good professor." Nia spoke about how she borrowed books from her instructor, and when she returned them, she ended up spending almost an hour talking with her.

Seven participants mentioned specific ways in which their first-year seminar instructors demonstrated they cared or were concerned for the students. For example, Jennifer described how her CU 101 instructor reached out to her after she earned a low score on an academic confidence survey:

We've been talking by e-mail recently about my score on the academic confidence test. She just talks to us, and I really like her a lot. I'm one of those people who asks a lot of questions, but I think I can ask her anything; she just cares.

Anna also shared an example of how her instructor contacted her because he was concerned. Anna said that after she became ill and hospitalized, her instructor was willing to help her when she was well enough to return to class. With her 
instructor's help, Anna was able to make up the material she missed so she did not have to withdraw from the class.

\section{Connection to Peers}

In addition to developing a connection with their first-year seminar instructor, seven of the participants got to know other students in the course, and some developed friendships that extended beyond the class. Marco said that his first-year seminar was the one opportunity he had to connect with other students in his major. Because he was primarily taking general education courses, Marco's major-specific section of the seminar helped introduce him to other students in the business major. For some, the first-year seminar provided an opportunity to expand their network of friends by meeting students outside of their major. Libby changed from a major-specific section to a general section so she could get to know other students:

I knew the rest of my classes would be really big, so I wanted to take a small class where I could get to know more people. I was originally in a nursing one, but I changed because I'll be with those people for the next four years. I want to get to know other people, so I changed.

Like Libby, Jessica took a first-year seminar section that provided her with an opportunity to get to know students in other majors- "CU 101 definitely gives you a cross-section of people. There's a wide variety of people from around campus in my section." Jessica further explained,

$I^{\prime} m$ already living in a dorm with kids in my major, so I'm already connected with people I'm going to class with. I like the fact that it's just a general section, and I don't really see these people all the time. We have different interests that connect us together, more than just classes.

Although a self-described, outgoing person, Kristy, a student from Minnesota, said that one of her greatest concerns about moving far away from home was making friends. She found her general section of the first-year seminar, one of her smallest classes (her biology lab was approximately the same size), to be helpful for meeting new people: "I went to lunch today with a couple of the girls from my CU 101 class. You really get to know the people in your class and become friends with them." Claire, a student in a major-specific section of the seminar, had a similar experience: "I have a couple of friends from the class. We go to lunch and see each other around all the time."

\section{Discussion and Implications for Practice}

Although the first-year seminars in this study varied in credit hours and specific course content, there were no significant differences in the participants' perceptions concerning the impact of the courses. All of the seminars in the study helped students feel more academically confident by reinforcing college success 
skills and strategies. Additionally, the relationships that participants developed with their peers and first-year seminar instructors helped them feel more comfortable. Although individual experiences varied, the participants' perceptions of the impact of first-year seminar participation on their early college experience were largely positive. These perceptions, while focused on experiences in first-year seminars, can help orientation/transition professionals identify issues concerning the college transition.

In this study, issues relating to academic confidence consistently emerged through the student narratives as being one of the more significant adjustments the participants made in their college transition. The first-year seminars in this study appeared to provide students with opportunities to learn about aspects of the college experience that could contribute to future academic success. For example, classroom interactions and activities, information about campus resources and learning strategies, even reaction or opinion papers may have helped participants feel more confident about their academic abilities. At the time the interviews were conducted, all but two participants indicated they were earning an " $\mathrm{A}$ " in their first-year seminar. When asked about other academic courses, none indicated they were earning less than a "B."

Further analysis suggested that first-generation students in the study were more likely than their peers to have perceptions that related to gains in academic confidence. This finding was particularly interesting because often it is assumed that first-generation students may lack academic skills compared to their second-generation peers, when in reality they may just lack academic confidence that manifests in their concern over the academic transition to college. Compared to second-generation peers who may have greater concerns about making friends and fitting in (Terenzini, P. T., Springer, L., Yaeger, P., Pascarella, E. T., \& Nora, A., 1996), first-generation students in the study benefited from interactions and activities in the first-year seminar that reinforced to them that they could perform well at college level. Similarly, orientation programs can help students begin to feel more confident academically by providing opportunities (e.g., "mock" classes offered during orientation or welcome week activities) to learn about the academic skills needed to succeed in college.

The findings in this study demonstrate the importance of developing relationships during the early college experience. The participants described activities and assignments in the first-year seminars that helped them get to know each other and their seminar instructor. Through these interactions, participants developed friendships, and they became acquainted with seminar instructors whom they described as caring, friendly, helpful, concerned, and approachable. The perceptions about the first-year seminar instructors in this study are particularly important in the context of the academic transition. Interactions with faculty and staff members that result in feelings of support can help first-year students develop academic competence (Reason, Terenzini, \& Domingo, 2006), which can lead to academic success (Pascarella \& Terenzini, 1977, 1978).

In this study, the students' narratives described perceptions of support. Even when participants did not perceive the content of the first-year seminar as useful to them, they all expressed perceptions of support from the faculty and staff who 
were teaching the course. Orientation and first-year programs play a vital role in helping to establish these relationships, and it is often during these initial interventions that students first meet peers, professors, and academic advisors. Given this finding, faculty, staff, and students who work with orientation and transition programs should provide ample formal and informal opportunities for students to begin to develop these relationships.

Although this research provides a glimpse of first-year seminars in the context of the early college transition, there is much more to learn about this experience. Interviewing students later in their first year may help discern any differences in perceptions of impact that may be related to credit hours earned in the first-year seminar. Further, because the first-year seminars in this study were part of a larger range of programs for students, additional information about the college transition can be gained by examining other programs offered at each of the institutions in the study. For example, asking students about information learned or friendships developed during orientation could provide additional ideas about how these programs and classes can work together to help students better negotiate the transition to the first college year.

\section{References}

Bogdan, R. C., \& Biklen, S. K. (1998). Qualitative research for education: An introduction to theory and methods. Needham Heights, MA: Allyn \& Bacon.

Boudreau, C. A., \& Komrey, J. D. (1994). A longitudinal study of the retention and academic performance of participants in freshmen orientation courses. Journal of College Student Development, 35, 444-449.

Davis, B. O., Jr. (1992). Freshman seminar: A broad spectrum of effectiveness. Journal of the Freshman Year Experience, 4(1), 79-94.

Fidler, P. P. (1991). Relationship of freshman orientation seminars to sophomore return rates. Journal of the Freshman Year Experience, 3(1), 7-38.

Fitts, C. T., \& Swift, F. H. (1928). The construction of orientation courses for college freshmen. University of California Publications in Education, 1897-1929, 2(3), 145-250.

Gordon, V. N. (1989). Origins and purposes of the freshman seminar. In M. L. Upcraft, J. N. Gardner, and Associates, The freshman year experience: Helping students survive and succeed in college (pp. 183-197). San Francisco, Jossey-Bass.

Gordon, V. N., \& Grites, T. J. (1984). The freshman seminar course: Helping students succeed. Journal of College Student Personnel, 25, 315-320.

Griffin, A., Romm, J., \& Tobolowsky, B. F. (2008). The first-year seminar characteristics. In B. F. Tobolowsky \& Associates, 2006 National Survey of First-Year Seminars: Continuing innovations in the collegiate curriculum (Monograph No. 51, p. 11-62). Columbia, SC: University of South Carolina, National Resource Center for the First-Year Experience and Students in Transition. 
Hunter, M. S., \& Linder, C. W. (2005). First-year seminars. In M. L. Upcraft, J. N. Gardner, \& B. O. Barefoot (Eds.), Challenging \& supporting the first-year student: A handbook for improving the first year of college (p. 275-291). San Francisco: Jossey-Bass.

Hunter, M. S., Skipper, T. L., \& Linder, C. W. (2003). The first-year seminar: Continuing support for new student transitions. In J. A. Ward-Roof \& C. Hatch (Eds.), Designing successful transitions: A guide for orienting students to college (Monograph No. 13, 2nd Ed., p. 149-163). Columbia, SC: University of South Carolina, National Resource Center for The First-Year Experience and Students in Transition.

Maisto, A. A., \& Tammi, M. W. (1991). The effect of a content-based freshman seminar on academic and social integration. Journal of the Freshman Year Experience, 3(2), 29-47.

Pascarella, E. T., \& Terenzini, P. T. (1977). Patterns of student-faculty informal interaction beyond the classroom and voluntary freshman attrition. The Journal of Higher Education, 48(5), 540-552.

Pascarella, E. T., \& Terenzini, P. T. (1978). Student-faculty informal relationships and freshman year educational outcomes. The Journal of Educational Research, 71(4), 183-189.

Patton, M. Q. (1990). Qualitative evaluation and research methods (2nd ed.). Beverly Hills, CA: Sage Publications.

Porter, S. R., \& Swing, R. L. (2006). Understanding how first-year seminars affect persistence. Research in Higher Education, 47(1), 89-109.

Reason, R. D., Terenzini, P. T., \& Domingo, R. J. (2006). First things first: Developing academic competence in the first year of college. Research in Higher Education, 47(2), 149-175.

Sanders, L., \& Burton, J. D. (1996). From retention to satisfaction: New outcomes for assessing the freshman experience. Research in Higher Education, 37(5), 555-567.

Schnell, C. A., \& Doetkott, C. D. (2002-2003). First year seminars produce long-term impact. Journal of College Student Retention, 4(4), 377-391.

Schwitzer, A. M., McGovern, T. V., \& Robbins, S. B. (1991). Adjustment outcomes of a freshman seminar: A utilization-focused approach. Journal of College Student Development, 32(6), 484-489.

Shanley, M. G., \& Witten, C. H. (1990). University 101 freshman seminar: A longitudinal study of persistence, retention, and graduation rates. NASPA Journal, 27(4), 344-352.

Starke, M. C., Harth, M., \& Sirianni, F. (2001). Retention, bonding, and academic achievement: Success of a first-year seminar. Journal of The First-Year Experience and Students in Transition, 13(2), 7-35.

Terenzini, P. T., Springer, L., Yaeger, P. M., Pascarella, E. T., \& Nora, A. (1996). First-generation college students: Characteristics, experiences, and cognitive development. Research in Higher Education, 37(1), 1-22.

Weissman, J., and Magill, B. A. (2008). Developing a student typology to examine the effectiveness of first-year seminars. Journal of The First-Year Experience \& Students in Transition, 20(2), 65-90. 